\title{
OXIDE MINERAL INCLUSIONS IN PYROPES FROM THE INTERNATIONALNAYA KIMBERLITE PIPE, YAKUTIA
}

\author{
Rezvukhin $^{1}$ DI, Malkovets ${ }^{1}$ VG, Gibsher ${ }^{1 *}$ AA, Kuzmin ${ }^{1,3}$ DV, Griffin ${ }^{2}$ WL, Pokhilenko ${ }^{1}$ NP, O'Reilly ${ }^{2}$ SY \\ ${ }^{1}$ V.S. Sobolev Institute of Geology and Mineralogy, Novosibirsk, Russia \\ ${ }^{2}$ Max-Planck Institute of Chemistry, Postfach 3060, Mainz, 55020, Germany \\ ${ }^{3}$ GEMOC National Key Centre, Macquarie University, Sydney, Australia
}

\section{INTRODUCTION}

Archean cratons are underlain by highly depleted subcontinental lithospheric mantle (SCLM). Studying the deep structure, compositional features and evolution of the SCLM is one of the major problems of mantle petrology. Kimberlite pipes bring to the surface a wide variety of mantle xenoliths and xenocrysts which provide the direct information about composition of the deepest parts of the lithospheric mantle. Xenolith and xenocryst data suggest that Archean SCLM has been extensively refertilized by metasomatic processes, with the addition of $\mathrm{Fe}$, $\mathrm{Ca}$, and $\mathrm{Al}$ to depleted protoliths. There is increasing evidence of the metasomatic origin of garnets in the cratonic subcontinental lithospheric mantle. The distribution of sub-calcic garnets in the SCLM beneath the Siberian craton suggests: (1) sub-calcic garnets and diamonds are metasomatic phases in the cratonic SCLM; (2) the distribution of both phases is laterally heterogeneous on relatively small scales and related to ancient structural controls (Malkovets et al., 2007). Since the end of the 1960s mineral inclusions in diamonds have been studied in great detail (e.g. Stachel and Harris, 2008). On the basis of these data substantial progress has been reached in our understanding of diamond- genesis processes. However, studies devoted to inclusions in pyrope are extremely rare; thus inclusions in pyrope have not been studied well, but they can provide valuable information about the genesis of this mineral in the upper mantle, which is still unclear.

\section{SAMPLE DESCRIPTION}

The pyrope crystals investigated in this work are from heavy mineral concentrate of the kimberlite pipe Internatsionalnaya, Malobotuobia field. The size of the grains ranges from two to eight $\mathrm{mm}$. Those containing either single or multiple inclusions were polished to reveal them on flat surfaces. The sectioned inclusions were then analyzed mostly using electron probe microanalyzers JEOL 8200 Super Probe (MaxPlanck Institute, Mainz, Germany) and JEOL JXA-8100 (Institute of Geology and Mineralogy, Novosibirsk, Russia).

\section{MINERALOGY}

\section{PYROPES}

The pyrope garnets belong to different parageneses within the ultramafic association, dominated by lherzolite paragenesis (Fig.1). Inclusions of rutile and picroilmenite also have been found in orange low-Cr garnets of the eclogite association. The presence of large inclusions of picroilmenite in eclogitic garnet is of particular importance, as picroilmenite is a characteristic mineral of the megacryst association, which also includes red Ti-garnet, clinopyroxene, phlogopite, olivine, etc. 


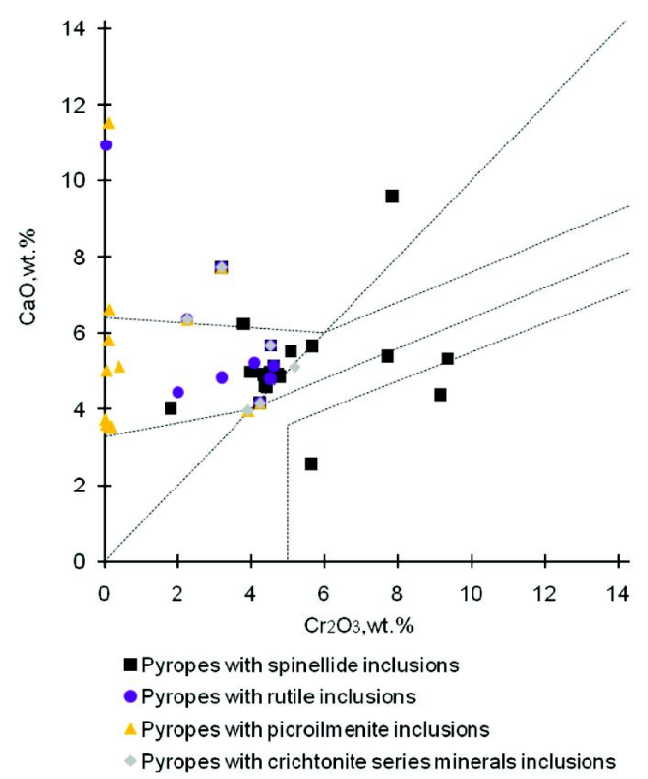

Figure 1. $\mathrm{CaO}$ vs $\mathrm{Cr}_{2} \mathrm{O}_{3}$ for pyropes with oxide inclusions.

\section{OXIDES}

Oxide minerals are fairly common as inclusions in pyrope. Phases identified and analyzed include chrome spinelides, picroilmenite, rutile and its variations (Cr-bearing, chromium-niobium) and minerals of the crichtonite series. Pyropes can contain either only one type of inclusions or various combinations thereof. A few samples are characterized by the presence of all four differentoxide phases in a single pyrope. Sometimes combined occurrence of oxides with silicates and/or sulfides is observed in a single pyrope host.

\section{MORPHOLOGY}

Oxide inclusions are usually present as elongated, needle or blade-like structures with rounded or polygonal cross-section, laths, tablets, and prisms with different facets are also common. The amount of oxide inclusions in a garnet varies greatly from single needles/laths to an extremely large number of them in some samples. The minimum thickness of elongated inclusions is a fraction of a micron, the maximum thickness (among those analyzed in the current work) is a grain of chromite $(\sim 0.2 \mathrm{~mm})$. The formation of these large inclusions of Cr-spinel is probably due to the active processes of coalescence, during which the confluence of smaller inclusions and progressive thickening of the individual minerals occurs, accompanied by change of inclusion shape (Afanasiev et al., 2001). Chrome spinelides with isometric shapes are abundant. Spherical to elliptical forms are more common; inclusions with well-defined octahedral facets are less common. According to existing ideas such isometrization occurs in the further evolution of needle-like inclusions (Geguzin, 1974, 1975).

Most inclusions are black; large grains also have resinous lustre. Needles of rutile can be brown, gray to colorless, often transparent.

Needles often define a regular spatial arrangement in pyrope matrix. The angle between crossing needles is $\sim 71$ degrees (the angle between triad axes in garnet). Such a strict orientation of the inclusions in the garnet structure has been a starting point for the assumption that at least part of needle-like inclusions formed as a result of exsolution (McGetchin and Silver, 1970; Hunter and Smith, 1981; Smith, 1987).

In some cases inclusions may consist of several phases that change along a single direction (usually along the elongation). Coexistence of oxide and silicate minerals, forming one inclusion is common. Sometimes the result of the collapse of needles on individual links can be seen - former parts of the whole elongated arrangement are now separated by the substance of enclosing garnet. Around these inclusions small isometric phases are observed with compositions similar to those of needles and laths. All this points to a complex evolution of needle-like inclusions, with several of steps, such as a gradual decrease in inclusion thickness, breakup and subsequent isometrization. 


\section{COMPOSITIONAL FEATURES}

Different oxide mineral compositions can be clearly seen on binary diagrams with $\mathrm{TiO}_{2}$ content on one axis. Spinelids form a distinct field with a high content of $\mathrm{Cr}_{2} \mathrm{O}_{3}$ and low $\mathrm{TiO}_{2}$. On another axis, any other component can be chosen, or their sum (e.g. $\mathrm{FeO}+\mathrm{MgO})$.

Chemical compositions of oxide inclusions in pyropes of the Internatsionalnaya pipe are shown in Fig. 2 (a-c). For comparison, the compositions of the following minerals are presented: 1) rutile inclusions in crustal almandine garnets of the Maiskaya pipe 2) rutiles from heavy mineral concentrate of the Internatsionalnaya pipe, and 3) oxides (mainly
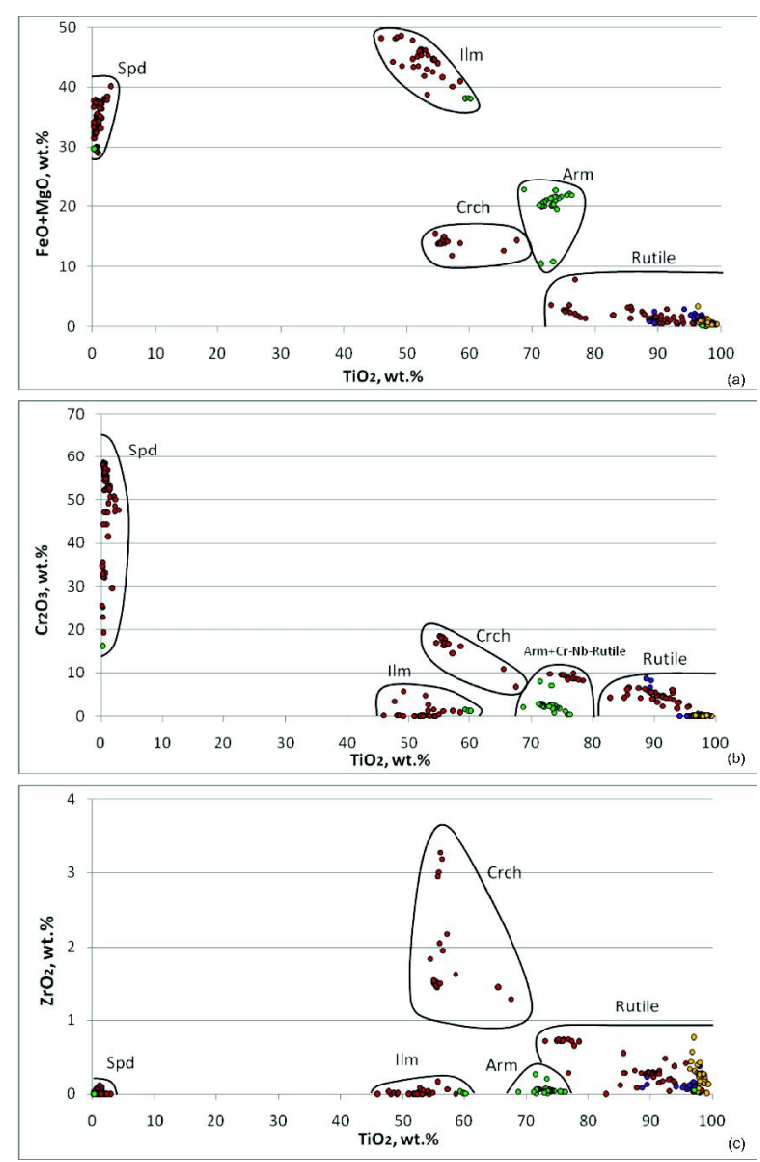

Figure 2 (a-c) Composition of oxide mineral inclusions in coordinates $\mathrm{TiO}_{2}-\mathrm{FeO}+\mathrm{MgO}(\mathrm{a}), \mathrm{TiO}_{2}-\mathrm{Cr}_{2} \mathrm{O}_{3}$ (b), $\mathrm{TiO}_{2}-\mathrm{ZrO}_{2}$ (c) armalkolites $\left.(\mathrm{Mg}, \mathrm{Fe}) \mathrm{Ti}_{2} \mathrm{O}_{5}\right)$ in lherzolite interstices, Vitim volcanic field (Litasov et al, 2006).

Oxide inclusions in pyropes from the Internatsionalnaya pipe

Rutiles from concentrate of the Internatsionalnaya pipe

Rutiles in crustal garnets from the Maiskaya pipe

Oxides (mainly armalkolites) in lherzolite interstices, Vitim volcanic field (Litasov et al, 2006).

\section{CHROME SPINELIDS}

Spinelids are the most common oxide inclusions in pyropes from the Internatsionalnaya pipe and are characterized by the general formula $(\mathrm{Fe}, \mathrm{Mg})(\mathrm{Cr}, \mathrm{Al}, \mathrm{Fe})_{2} \mathrm{O}_{4} . \mathrm{MgO}$ contents range from 8.7 to 18 wt. \%, $\mathrm{FeO}$ - from 15.7 to 28.7 $\mathrm{wt} \%$. Contents of elements in the octahedral positions vary even more significantly: $\mathrm{Cr}_{2} \mathrm{O}_{3}$ from 19.3 - 60.8 wt. $\%, \mathrm{Al}_{2} \mathrm{O}_{3}$ - from 5.4 - 42.9 wt. $\%$. $\mathrm{TiO}_{2}$ content is less than 3.0 wt. $\%$, and rarely exceeds $1.5 \%$.

\section{PICROILMENITE}

Picroilmenite, a member of the isomorphous series ilmenite - geikielite $\left(\mathrm{FeTiO}_{3}-\mathrm{MgTiO}_{3}\right)$ characterized by a high content of $\mathrm{Mg}$, has been recovered in garnets of ultrabasic and eclogitic parageneses. The main difference between picroilmenites of these parageneses is in the content of $\mathrm{Cr}$ - ultrabasic picroilmenite is more chromium-rich and may contain up to $5.7 \mathrm{wt} . \%$ $\mathrm{Cr}_{2} \mathrm{O}_{3}$ in form of eskolaite component. There is a direct correlation between garnet and picroilmenite $\mathrm{Cr}_{2} \mathrm{O}_{3}$ content.

\section{RUTILE}

Needle-like inclusions of rutile $\left(\mathrm{TiO}_{2}\right)$ in pyrope are not uncommon, but their presence is 
of particular interest. According to modern ideas, rutile does not occur in rocks of peridotite paragenesis, so its presence in the form of intergrowths with pyrope can serve as additional confirmation of the metasomatic origin of the pyrope.

The chemical compositions of rutiles from pyropes of the Internatsionalnaya kimberlite pipe (ultrabasic paragenesis) has been compared with those of rutiles in crustal garnets from the Maiskaya pipe (Fig. 3). Rutile inclusions of various paragenesises are characterized by notable differences in the types and contents of impurities. Rutiles in crustal garnets have much lower contents of minor elements and have a $\mathrm{TiO}_{2}$ content about 96-99 wt.\%,; among minor elements the miot abundant are $\mathrm{Fe}$ and $\mathrm{Zr}$. In contrast, rutiles in garnets from ultramafic (lherzolite) paragenesis are highly enriched in impurities. As a rule, these are mainly $\mathrm{Cr}$, $\mathrm{HFSE}\left(\mathrm{Nb}, \mathrm{Ta}, \mathrm{Zr}\right.$ ), and $\mathrm{Fe} . \mathrm{TiO}_{2}$ contents are th"s much lower, and often far from 100 wt. $\% . \mathrm{Nb}_{2} \mathrm{O}_{5}$ contents in rutile of mantle pyrope vary from 0.1 to $9.5 \mathrm{wt} \%, \mathrm{Cr}_{2} \mathrm{O}_{3}$ from 2 to 10 wt. $\%, \mathrm{Al}_{2} \mathrm{O}_{3}$ up to 3.8 wt. $\%, \mathrm{FeO}$ up to 6.5 wt. \%. Comparatve contents in rutile from crustal garnets are: $\mathrm{Nb}_{2} \mathrm{O}_{5}$ up to 0.3 wt. $\%, \mathrm{Cr}_{2} \mathrm{O}_{3}$ up to 0.4 wt. $\%, \mathrm{Al}_{2} \mathrm{O}_{3}$ up to 1.5 wt. $\%, \mathrm{FeO}$ up to 3.2 wt. $\%$.

Particularly noteworthy are chromiumniobium rutiles from sample INT-5, which have

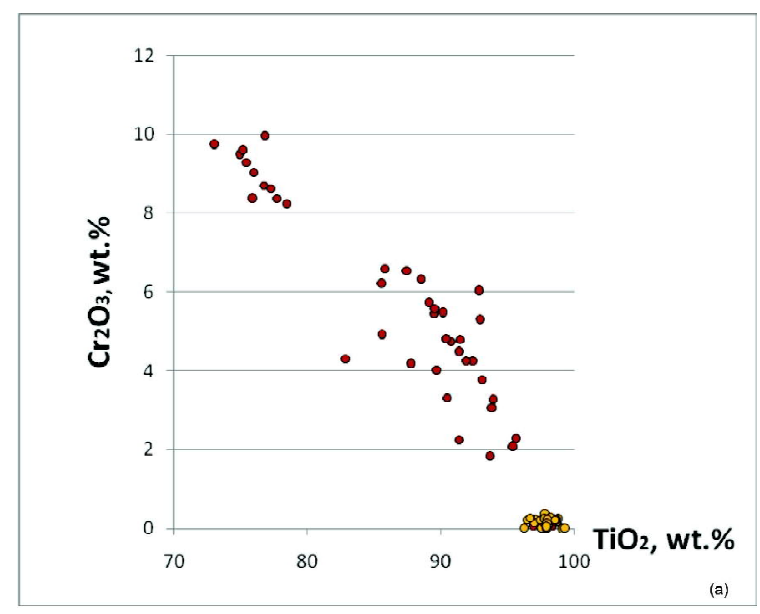

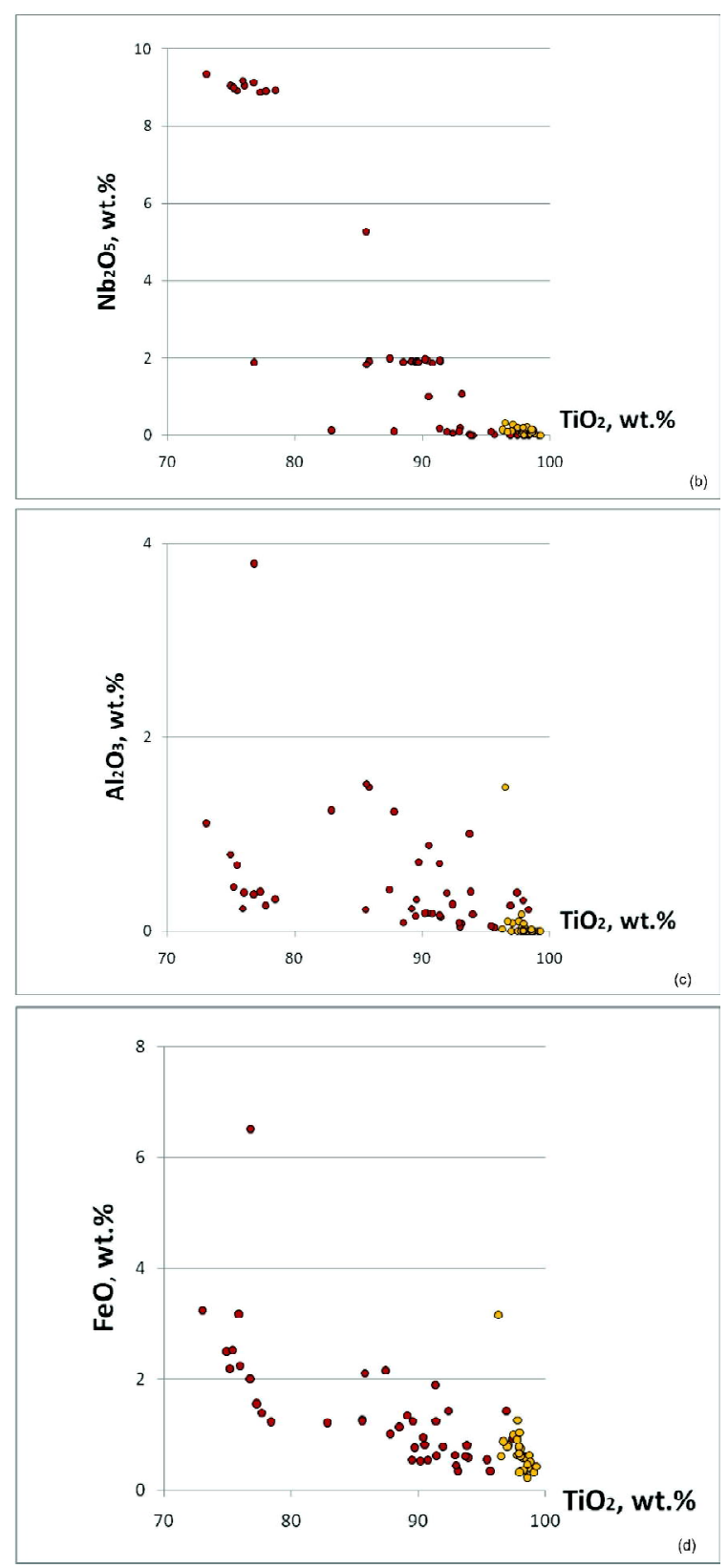

Figure 3 (a-d) Compositions of rutile inclusions in coordinates $\mathrm{TiO}_{2}$ $\mathrm{Cr}_{2} \mathrm{O}_{3}(\mathrm{a}), \mathrm{TiO}_{2}-\mathrm{Nb}_{2} \mathrm{O}_{5}$ (b), $\mathrm{TiO}_{2}-\mathrm{Al}_{2} \mathrm{O}_{3}$ (c), $\mathrm{TiO}_{2}-\mathrm{FeO}$ (d).

Rutiles in pyropes from the Internatsionalnaya pipe

Rutiles in crustal garnets from the Maiskaya pipe 


\section{0 $^{\text {th }}$ International Kimberlite Conference, Bangalore - 2012}

one of the highest contents of HFSE-elements among all rutile inclusions in garnet described in the literature. Contents of $\mathrm{Cr}_{2} \mathrm{O}_{3}$ and $\mathrm{Nb}_{2} \mathrm{O}_{5}$ reach 10 and 9.5 wt.\% respectively, HFSE content is over $12 \mathrm{wt} \%$. $\mathrm{TiO}_{2}$ content is near $75 \mathrm{wt} \%$. Such a huge enrichment of rutile inclusions in highly incompatible elements clearly indicates simultaneous crystallization of rutile and pyrope from fluids enriched in HFSE. Typical contents of $\mathrm{Nb}$ in pyropes rarely reach $100 \mathrm{ppm}$, and thus the formation of $\mathrm{Nb}$-rich rutiles by solid solution breakdown is very unlikely.

As for $\mathrm{Cr}_{2} \mathrm{O}_{3}$, its high content directly indicates the type of association. HFSE-elements may not be present in rutile, but the content of $\mathrm{Cr}_{2} \mathrm{O}_{3}$ in rutile of mantle garnets is always higher than 2 wt.\% (see figure 3). Also the following relationship is observed: the more chromium in the host pyrope, the higher its content in the inclusions of rutile. In crustal almandine $\mathrm{Cr}_{2} \mathrm{O}_{3}$ contents are very low $(<0.3$ wt. $\%)$, and rutile inclusions also have a very low content of $\mathrm{Cr}_{2} \mathrm{O}_{3}$, which does not exceed $0.4 \mathrm{wt}$ \% of particular note is sample INT-29. This orange garnet belongs to the eclogitic paragenesis. It is low in $\mathrm{Cr}_{2} \mathrm{O}_{3}$ and has a very high content of $\mathrm{CaO}$ (about $11 \mathrm{wt} \%$ ). Analyzed rutile inclusions contain small amounts of impurities, and their composition is almost completely analogous to the rutiles from crustal garnets of the Maiskaya pipe.

Thus, the chemical composition of rutile as inclusions in garnet clearly reflects its paragenetic identity. Rutiles from mantle garnets are characterized by a high content of $\mathrm{Cr}_{2} \mathrm{O}_{3}$

and in some cases, a high content of HFSE. Rutiles from crustal garnets in general are characterized by low minor- element contents. For a detailed characterization of rutiles in pyrope of the eclogitic paragenesis there is not enough data at this stage.

On the basis of these data on the chemical composition of rutile and by using the diagrams $\mathrm{TiO}_{2}-\mathrm{Cr}_{2} \mathrm{O}_{3}$ and (to some extent) $\mathrm{TiO}_{2}-\mathrm{Nb}_{2} \mathrm{O}_{5}$ rutiles can clearly be assigned to mantle or to crustal paragenesse. The most distinctive feature is the high content of $\mathrm{Cr}_{2} \mathrm{O}_{3}$ in the rutiles of mantle paragenesis. The results can be used as reliable application in prospecting for kimberlite bodies.

\section{MINERALS OF CRICHTONITE SERIES}

Minerals of the crichtonite series have rather complicated compositions and structures. The general formula for the group is $\mathrm{AM}_{21} \mathrm{O}_{38}$, where site A takes cations with a large radius $(\mathrm{Sr}, \mathrm{Pb}$, REE, U, Ca, Na, K, Ba), and site $\mathrm{M}$ takes smaller cations ( $\mathrm{Ti}, \mathrm{Fe}, \mathrm{Cr}, \mathrm{Al}, \mathrm{Zr}, \mathrm{Mg}$ ). The name of the mineral is defined by the dominant cation in $\mathrm{A}$ position: $\mathrm{Sr}$ for crichtonite, $\mathrm{Ca}$ - loverengite, $\mathrm{Na}$ landauite, $\mathrm{Pb}$ - senaite, REE - davidite, $\mathrm{Ba}$ lindsleyite, $\mathrm{K}$ - mathiasite (Rouse and Peacor 1968; Grey et al. 1976; Gatehouse et al. 1978; Haggerty et al. 1983).

Chemical compositions may vary greatly but the distinctive feature of the minerals of this group is enrichment in incompatible and rare elements. Also, it is generally accepted that the minerals of the crichtonite series in mantle rocks reflect mantle metasormatism, with the metasomatic enviroment being enriched in incompatible elements and volatiles (Erlank and Rickard 1977; Jones et al. 1982; Jones 1989; Haggerty 1983, 1991a). The presence of such rare minerals as inclusions in pyrope strongly supports a model of pyrope crystallization from metasomatic fluids enriched in incompatible elements.

\section{CR CONTENTS OF GARNET HOST AND INCLUSIONS}

As noted above, the composition of the inclusions may reflect the geochemical conditions of their formation.

Fig. 4 shows the relationship between $\mathrm{Cr}_{2} \mathrm{O}_{3}$ content in various types of inclusions with the $\mathrm{Cr}_{2} \mathrm{O}_{3}$ content of ther garnet host. There is anobvious positive correlation, which suggest that 


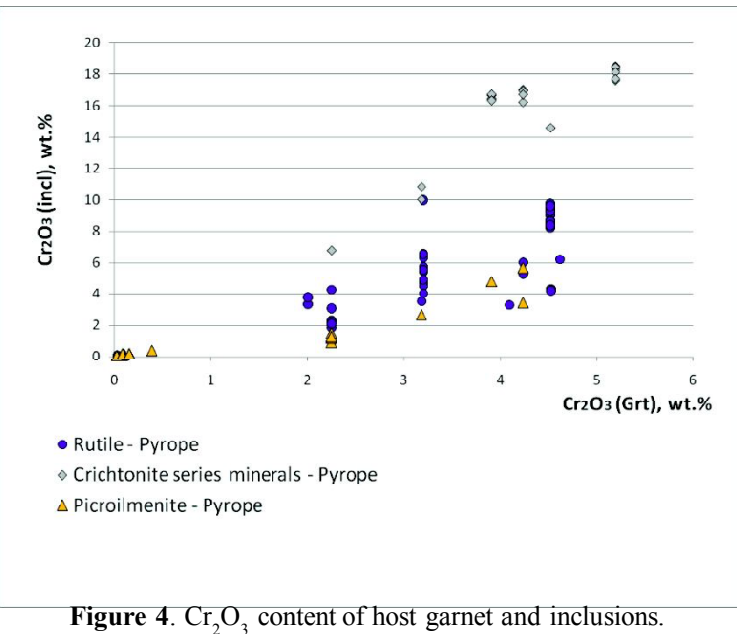

the pyrope host and its inclusions are in equilibrium in terms of $\mathrm{Cr}$.

\section{SUMMARY AND CONCLUSIONS}

During studying of oxide mineral inclusions in garnets from heavy mineral concentrate of the kimberlite pipe Internatsionalnaya have been discovered and analyzed such mineral phases as chrome spinelids, picroilmenite, rutile and crichtonite-series minerals. The most common inclusions are chrome spinelids, which are one of the rock-forming minerals of lithospheric mantle peridotites.

The presence of inclusions of rutile enriched in $\mathrm{Nb}$ and $\mathrm{Ta}$, picroilmenite and rare crichtoniteseries minerals, enriched in incompatible elements such as LILE, HFSE, REE, whose genesis is conventionally associated with the processes of mantle metasomatism, suggests that at least some of the pyropes have been formed from fluids related to mantle metasomatism. At this stage of the study we cann't determine the nature and type of metasomatic fluid/melt, from which such pyropes crystallized. This requires further detailed geochemical studies.

The data obtained on the chemical composition of rutiles as inclusions in garnets of mantle and crust associations make in possible by using diagrams $\mathrm{TiO}_{2}-\mathrm{Cr}_{2} \mathrm{O}_{3}$ and $\mathrm{TiO}_{2}-\mathrm{Nb}_{2} \mathrm{O}_{5}$ to refer such rutiles to one of these assemblages. The most distinctive feature is the high content of $\mathrm{Cr}_{2} \mathrm{O}_{3}$ in rutiles of mantle paragenesis. These results can be used as reliable indicators in prospecting for kimberlite bodies.

\section{References}

Afanasiev VP, Zinchuk NN, Pokhilenko NP (2001). Morphology and morphogenesis of kimberlite indicator minerals (in Russian). Izd. SO RAN, Filial Geo, Novosibirsk, 276 pp.

Erlank AJ, Rickard RS (1977). Potassic richterite bearing peridotites from kimberlite and the evidence they provide for upper mantle metasomatism. In: Extended Abstr, 2nd Int Kimberlite Conf, Santa Fe, New Mexico, USA, unpaged.

Gatehouse BM, Grey IE, Campbell IH, Kelly P (1978). The crystal structure of loveringite: a new member of the crichtonite group. Am Mineral 63: 28-36.

Geguzin YaE (1974). Essays on diffusion in crystals (in Russian). Izd. Nauka, 254 pp.

Geguzin YaE (1974). Mechanisms and kinetics of inclusion shape transformation in crystals (in Russian). Izd. Nauka, Problems of Modern Crystallography, pp. 110-127.

Grey IE, Lloyd DJ, White JJS (1976). The crystal structure of crichtonite and its relationship to senaite. Am Mineral 61:1203-1212.

Haggerty SE, Smyth JR, Erlank AJ, Rickard RS, Danchin RV (1983). Lindsleyite (Ba) and mathiasite (K): two new chromium titanates in the crichtonite series from the upper mantle. Am Mineral 68: 494-505.

Haggerty SE (1991a). Oxide mineralogy of the upper mantle. In:Lindsley DH, Ribbe HP (eds) Oxide minerals: petrological and magnetic significance. (Reviews in Mineralogy, 25) Mineral Soc Am, Washington, DC, pp 355-416.

Hunter WC, Smith D (1981). Garnet peridotite from Colorado Plateau ultramafic diatremes: hydrates, carbonates, and comparative geothermometry. Contrib Mineral Petrol 76: 312-320. 


\section{0 $^{\text {th }}$ International Kimberlite Conference, Bangalore - 2012}

Jones AP, Smith JV, Dawson JB (1982). Mantle metasomatism in 14 veined peridotites from Bultfontein mine, South Africa. J Geol 90: 435453.

Jones AP (1989). Upper-mantle enrichment by kimberlitic or carbonatitic magmatism. In: Bell K (ed) Carbonatites: genesis and evolution. Unwin Hyman Ltd, London, pp 448-463.

Litasov, K.D., Litasov, Yu.D., Malkovets, V.G., Taniguchi, H (2006). Mineralogical Study of Interstitial Phase Assemblages in Titaniferous Peridotite Xenoliths from Pliocene Basanites of Vitim Volcanic Field (Transbaikalia, Russia). Northeast Asian Studies, 10, pp. 161-175.

Malkovets, G., Grifûn, W.L., O'Reilly, S.Y., Wood, B.J. (2007) Diamond, subcalcic garnet and mantle metasomatism: kimberlite sampling patterns deûne the link. Geology 35, 339-342.

McGetchin TR, Silver LT (1970). Compositional relations in minerals from kimberlite and related rocks in the Moses Rock dike, San Juan County, Utah. Am Mineral 55: 1738-1771.

Rouse RC, Peacor DR (1968). The relationship between senaite, magnetoplumbite and davidite. Am Mineral 53: 869-879.

Smith D (1987). Genesis of carbonate in pyrope from ultramafic diatremes on the Colorado Plateau, southwestern United States. Contrib Mineral Petrol 97: 389-396.

Stachel T., Harris J.W. The origin of cratonic diamonds - constraints from mineral inclusions // 2008, Ore Geol. Rev., v. 34, p. 5-32. 